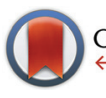

CrossMark $\leftarrow$ click for updates

Cite this: Dalton Trans., 2014, 43 14284

Received 19th March 2014,

Accepted 11th April 2014

DOI: $10.1039 / c 4 d t 00835 a$

www.rsc.org/dalton

\title{
Synthesis and thermal decomposition of a pyridylene-bridged bis- $\beta$-diketiminate magnesium hydride cluster $\uparrow$
}

\begin{abstract}
Sjoerd Harder, ${ }^{* a}$ Jan Spielmann $^{\mathrm{b}}$ and Julia Intemann ${ }^{\mathrm{a}, \mathrm{c}}$
Reaction of PYR-(MgnBu) $2_{2}$, in which PYR is 2,6-[(DIPP)NC(Me)CHC(Me)N- $]_{2}$-pyridine and DIPP is 2,6$i \mathrm{Pr}_{2}$-phenyl, with (DIPP) NH $\mathrm{BH}_{3}$ gave PYR-[MgNH(DIPP)BH $]_{2}$ (56\%) which was characterized by crystal structure determination. Addition of THF resulted in $\beta-\mathrm{H}$ elimination and formation of PYR- $[\mathrm{MgNH}(\mathrm{DIPP})-$ $\left.\mathrm{BH}_{3}\right](\mathrm{MgH}) \cdot \mathrm{THF}(57 \%)$, likewise characterized by crystal structure determination. Conversion of the second amidoborane anion in $\mathrm{H}^{-}$could not be achieved. Reaction of PYR-(MgnBu $)_{2}$ with $\mathrm{PhSiH}_{3}$ gave PYR$(\mathrm{MgH})_{2}$, which crystallized as a dimer. The structure of [PYR- $\left.(\mathrm{MgH})_{2}\right]_{2}$ shows an 8 -membered ring of $\mathrm{Mg}^{2+}$ and $\mathrm{H}^{-}$ions. Thermal decomposition at $130{ }^{\circ} \mathrm{C}$ releases one equivalent of $\mathrm{H}_{2}$, i.e. $50 \%$ of the expected value. Nucleophilic attack at the para-position and reduction of the pyridylene bridge might explain reduced $\mathrm{H}_{2}$ release.
\end{abstract}

\section{Introduction}

Transition metal hydride complexes play an important role in the broader context of organometallic chemistry and have paved the way for the early development of homogeneous transition metal catalysis. ${ }^{1}$ The extended class of late main group metal hydride compounds (e.g. alanes, boranes, stannanes) is also well-established and heavily used as reducing agents in organic synthesis. ${ }^{2}$ The early main group metal hydrides, however, suffer from their highly polar character, which results in ionic crystal structures, $(\mathrm{MH})_{\infty}$ and $\left(\mathrm{MH}_{2}\right)_{\infty}$, with very high lattice energies. $^{2,3}$ The latter are an obstacle in the synthesis of well-defined early main group metal hydride complexes like $\mathrm{L}^{0} \cdots \mathrm{M}-\mathrm{H}$ or $\mathrm{L}^{-1}-\mathrm{M}-\mathrm{H}$ (in which $\mathrm{L}^{0}$ and $\mathrm{L}^{-1}$ represent neutral and -1 charged ligand systems, respectively). The challenge of selectively synthesizing early main group metal hydride complexes was recently taken on, and the field is rapidly expanding..$^{4-15}$ This is especially due to rewarding contributions of the field to early main group metal catalysis ${ }^{16-19}$ and hydrogen storage. ${ }^{11,14}$

In light of this, $\beta$-diketiminate complexes of magnesium hydride (Scheme 1) have been shown to function as molecular models for the hydrogen storage system: $\mathrm{MgH}_{2} \rightleftarrows \mathrm{Mg}+$

\footnotetext{
${ }^{a}$ Inorganic and Organometallic Chemistry, University Erlangen-Nürnberg, Egerlandstrasse 1, 91058 Erlangen, Germany.E-mail: sjoerd.harder@fau.de ${ }^{b}$ Inorganic Chemistry, University Duisburg-Essen, Universitätsstrasse 5, 45117 Essen, Germany

${ }^{c}$ Stratingh Institute of Chemistry, University of Groningen, Nijenborgh 4, 9747 AG Groningen, Netherlands

†CCDC 992444-992446. For crystallographic data in CIF or other electronic format see DOI: $10.1039 / \mathrm{c} 4 \mathrm{dt} 00835 \mathrm{a}$
}

$\mathrm{H}_{2} \cdot{ }^{11,14,20}$ Apart from the magnesium hydride dimer $[(\mathrm{DIPPnacnac}) \mathrm{MgH}]_{2}$ (Scheme 1), ${ }^{9}$ larger magnesium hydride clusters based on bridged $\beta$-diketiminate ligands were introduced. ${ }^{11,14}$ The ligand with direct connection of $\beta$-diketiminate units gave the tetranuclear magnesium hydride cluster $\left[\mathbf{N N}-(\mathrm{MgH})_{2}\right]_{2} \cdot{ }^{14}$ Using a para-phenylene spacer gave a larger octanuclear cluster in which $\mathrm{MgH}_{2}$ is incorporated: [PARA- $\left.(\mathrm{MgH})_{2}\right]_{3}\left[\mathrm{MgH}_{2}\right]_{2}$ (Scheme 1). ${ }^{11}$ It was shown that these magnesium hydride complexes are stable towards thermal decomposition when dissolved in aromatic solvents. However, in the solid state, thermal decomposition with release of the expected amount of $\mathrm{H}_{2}$ is observed. As predicted by theoretical calculation, ${ }^{21}$ the hydrogen release temperatures $\left(120-200{ }^{\circ} \mathrm{C}\right)$ are much lower than that for bulk $\left(\mathrm{MgH}_{2}\right)_{\infty}$ $\left(>300{ }^{\circ} \mathrm{C}\right)$ and increase with the cluster size (Scheme 1). ${ }^{14}$ Hitherto, the low-valent products after $\mathrm{H}_{2}$ elimination could not be characterized. Also, reversibility has so far not been observed.

In continuation, we extend our investigations with the 2,6pyridylene bridged $\beta$-diketiminate ligand (PYR). This ligand has been shown to have unusual coordination chemistry. ${ }^{22-24}$ It can bridge a dimeric unit symmetrically with long, but not negligible pyridine-metal contacts (i) in Scheme 2. This leads to significant strain: the $\mathrm{N}-\mathrm{C}-\mathrm{N}$ angles in PYR-(MgnBu$)_{2}$ of circa $109^{\circ}$ are much smaller than the idealized $120^{\circ}$ value for $\mathrm{sp}^{2}$ hybridization. Also asymmetric coordination modes (ii) have been observed. Due to essential free rotation of the pyridylene unit in respect of the $\beta$-diketiminate NCCCN planes, another geometry with non-classic hydrogen $\mathrm{C}-\mathrm{H} \cdots \mathrm{N}$ bonding is feasible (iii). As the bimetallic complexes PYR- $(\mathrm{ZnR})_{2}$ were found to be completely inactive in $\mathrm{CO}_{2}$ /epoxide copolymeriza- 


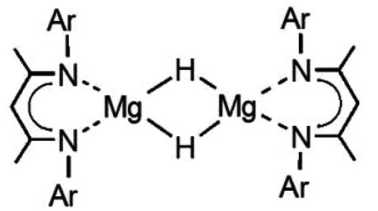

[(DIPPnacnac) $) \mathrm{MgH}]_{2}$<smiles>CC(C)c1cccc(C(C)C)c1SP=[Te]</smiles>
$120^{\circ} \mathrm{C}$ 1 equiv $\mathrm{H}_{2}$

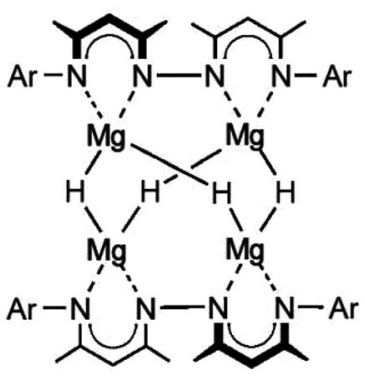

$\left[\mathrm{NN}-(\mathrm{MgH})_{2}\right]_{2}$

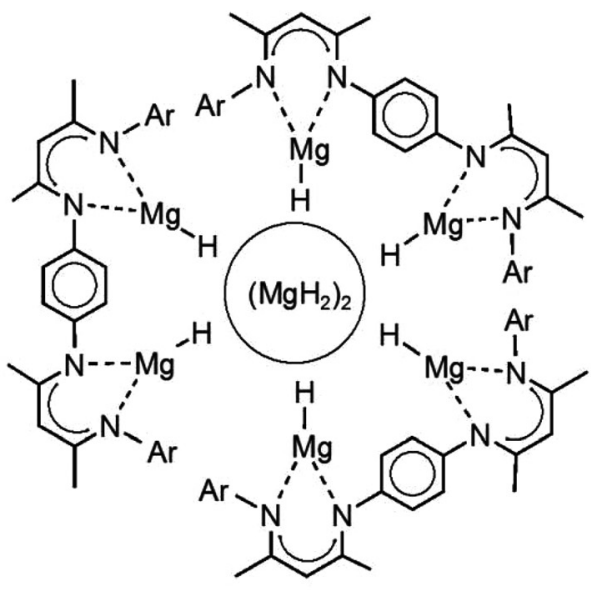

[PARA-(MgH $\left.)_{2}\right]_{3}\left[\mathrm{MgH}_{2}\right]_{2}$

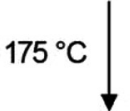

2 equiv $\mathrm{H}_{2}$

Scheme 1 Magnesium hydride complexes.

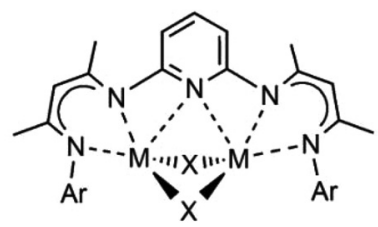

(i)

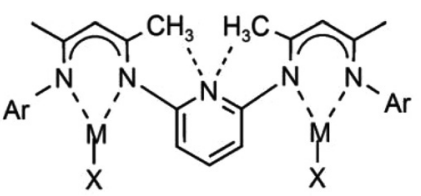

(iii)

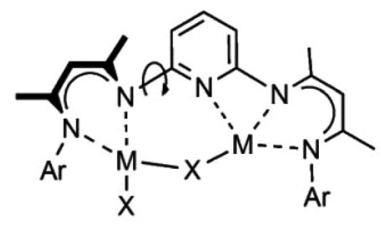

(ii)

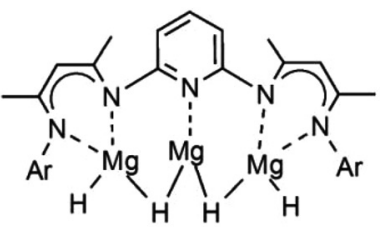

(iv)
Scheme 2 Coordination modes of the PYR ligand.

tion, it was reasoned that such a geometry might block metalmetal communication and synergistic effects.

The pyridylene bridge in PYR is potentially a strongly coordinating donor that also may assist in incorporation of additional metal units: a magnesium hydride complex like (iv) could be envisioned. Here, we evaluate the magnesium hydride chemistry of the PYR ligand.

\section{Results and discussion}

We recently reported a convenient high-yield method for the synthesis of $[(\text { DIPPnacnac) }) \mathrm{MgH}]_{2}$ by thermally induced $\beta-\mathrm{H}$ elimination in the magnesium amidoborane precursor (DIPPnacnac) $\mathrm{MgNH}(i \mathrm{Pr}) \mathrm{BH}_{3} .{ }^{23}$ The analogue bimetallic complex PYR- $\left[\mathrm{MgNH}(i \mathrm{Pr}) \mathrm{BH}_{3}\right]_{2}$ can be prepared according to Scheme 3, but thermal decomposition led to formation of a BNBNproduct, presumably through an hydride intermediate. ${ }^{23}$ We found that, in case of a 2,6- $i \mathrm{Pr}_{2} \mathrm{C}_{6} \mathrm{H}_{3}$ substituent (DIPP) on $\mathrm{N}$, the fate of thermal decomposition is different.

PYR-[MgNH(DIPP) $\left.\mathrm{BH}_{3}\right]_{2}$ was prepared by careful deprotonation of $\mathrm{H}_{2} \mathrm{~N}(\mathrm{DIPP}) \mathrm{BH}_{3}$ by PYR-(Mg $\left.n \mathrm{Bu}\right)_{2}$ at $-78{ }^{\circ} \mathrm{C}$. The low temperature is essential and prevents catalytic decomposition of $\mathrm{H}_{2} \mathrm{~N}$ (DIPP) $\mathrm{BH}_{3}$ in [(DIPP)NH $]_{2} \mathrm{BH}$ and $\mathrm{BH}_{3}$, as reported earlier. ${ }^{25}$ The product, which could be isolated in the form of yellow block-like crystals (56\%), has been characterized by crystal structure determination (Fig. 1a, Table 1). Its structure is similar to that of PYR- $\left[\mathrm{MgNH}(i \mathrm{Pr}) \mathrm{BH}_{3}\right]_{2}$ and shows a near $\mathrm{C}_{2}$-symmetric complex with two B,N-bridging amidoborane anions. Their $\mathrm{Mg} \cdots \mathrm{H}, \mathrm{Mg} \cdots \mathrm{B}$ and $\mathrm{Mg}-\mathrm{N}$ distances average

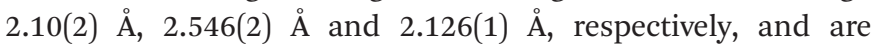
similar to those in the $i$ Pr-substituted complex. ${ }^{23}$

The pyridylene bridge is symmetrically bridging the two $\mathrm{Mg}$ ions with rather long distances of 2.7-2.8 $\AA$.

${ }^{1} \mathrm{H}$ NMR signals for PYR-[MgNH(DIPP)BH $\left.\mathrm{B}_{3}\right]_{2}$ in toluene- $d_{8}$ are, at room temperature, rather broad. Cooling the sample to $-50{ }^{\circ} \mathrm{C}$ gives a set of sharp signals which allow for unambiguous NMR characterization. The $\mathrm{NH}$ and $\mathrm{BH}_{3}$ groups show broad ${ }^{1} \mathrm{H}$ NMR signals at $3.13 \mathrm{ppm}$ and $2.28 \mathrm{ppm}$, respectively. The $i \operatorname{Pr}$ groups in the ligand give rise to four doublet and two septet resonances and the same was found for the $i$ Pr groups in the $\mathrm{NH}(\mathrm{DIPP}) \mathrm{BH}_{3}{ }^{-}$ion.

In contrast to a toluene solution of (DIPPnacnac)MgNH(DIPP) $\mathrm{BH}_{3}$, which decomposes into (DIPPnacnac) $\mathrm{MgN}(\mathrm{DIPP})=$ $\mathrm{BH}_{2}$ and $\mathrm{H}_{2}$ at forced conditions $\left(120{ }^{\circ} \mathrm{C}, 24\right.$ hours $),{ }^{23}$ 


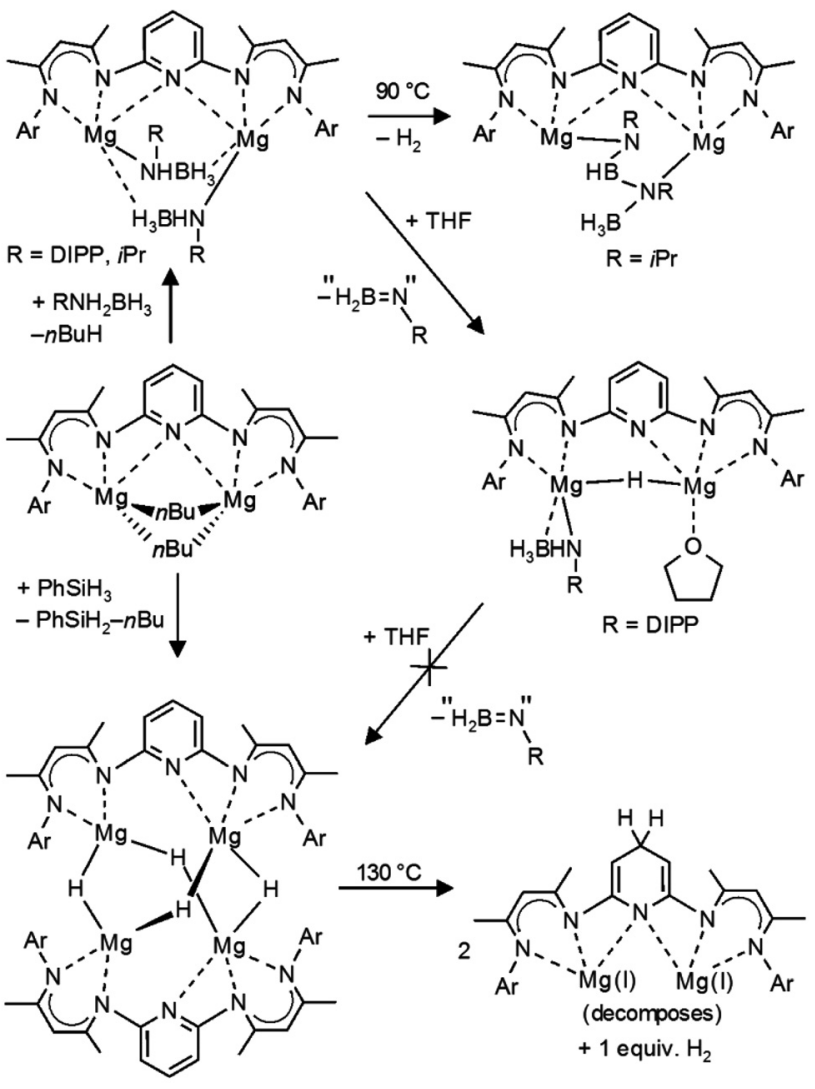

Scheme 3 Synthesis and decomposition of $\left[\text { PYR }-(\mathrm{MgH})_{2}\right]_{2}$.

a toluene solution of PYR-[MgNH(DIPP) $\left.\mathrm{BH}_{3}\right]_{2}$ already decomposes slowly at room temperature. A singlet ${ }^{1} \mathrm{H}$ NMR signal at $4.45 \mathrm{ppm}$ indicates $\mathrm{H}_{2}$ formation. ${ }^{11} \mathrm{~B}$ NMR spectra suggest formation of $[(\mathrm{DIPP}) \mathrm{NH}]_{2} \mathrm{BH}$ and the $\mathrm{BH}_{4}{ }^{-}$ion, but welldefined products could not be isolated.

Interestingly, addition of minor amounts of THF to a benzene solution of PYR-[MgNH(DIPP) $\left.\mathrm{BH}_{3}\right]_{2}$ initiated a fast decomposition reaction and resulted in precipitation of yellow crystals (Scheme 3). Structural characterization of the product revealed the occurrence of a single $\beta-\mathrm{H}$ elimination: PYR$\left[\mathrm{MgNH}(\mathrm{DIPP}) \mathrm{BH}_{3}\right](\mathrm{MgH}) \cdot \mathrm{THF}$. The crystal structure (Fig. 1b, Table 1) shows a binuclear molecule with symmetrical bridging of $\mathrm{H}^{-}$between the $\mathrm{Mg}^{2+}$ centers: 193(3) $\AA$ and 1.95(2) $\AA$. The remaining amidoborane anion binds only to Mg1. This unsymmetrical charge distribution of anions is balanced by strong coordination of the pyridylene bridge to $\mathrm{Mg} 2$ (2.199(2) ̊) and an additional THF ligand.

${ }^{1} \mathrm{H}$ NMR signals can be assigned unambiguously: the amidoborane part shows a broad $\mathrm{BH}_{3}$ signal at $1.58 \mathrm{ppm}$ and a quartet for $\mathrm{NH}$ at $2.61 \mathrm{ppm}\left({ }^{3} J(\mathrm{H}, \mathrm{H})=3.4 \mathrm{~Hz}\right)$ whereas the bridging $\mathrm{H}^{-}$gives a singlet at $3.21 \mathrm{ppm}$.

The mechanism for the here observed THF-induced $\beta-\mathrm{H}$ elimination is subject of speculation. In light of the fact that the preliminary step for $\beta$-hydrogen elimination generally requires a low-coordinate metal center with an agostic $\beta$-H $\cdots$ metal contact, ${ }^{26}$ addition of THF should rather
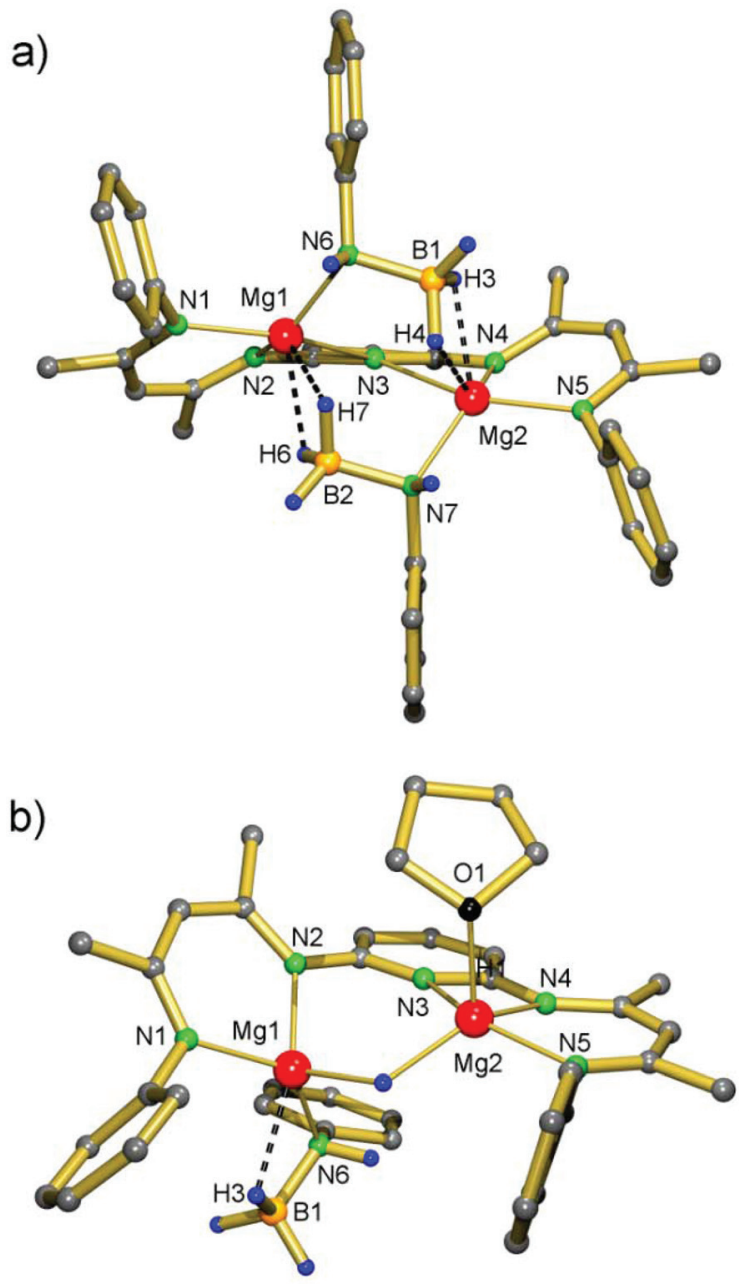

c)

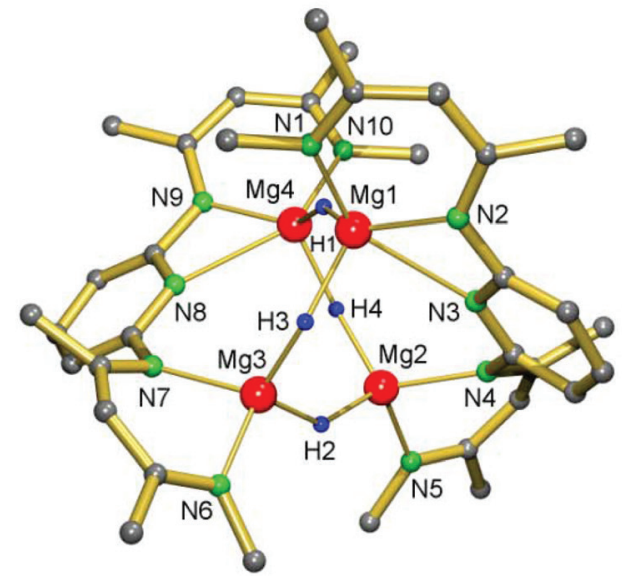

Fig. 1 Crystal structures of (a) PYR-[MgNH(DIPP)BH $]_{2}$, (b) PYR-[MgNH(DIPP) $\left.\mathrm{BH}_{3}\right](\mathrm{MgH}) \cdot \mathrm{THF}$ and (c) $\left[\mathrm{PYR}-(\mathrm{MgH})_{2}\right]_{2}$. In all cases, the $i$ Pr substituents of the DIPP are not shown for clarity (for [PYR- $\left.(\mathrm{MgH})_{2}\right]_{2}$ only the $\mathrm{C}_{\text {ipso }}$ atoms of DIPP are shown).

prevent such process. Lewis-base induced $\beta-\mathrm{H}$ eliminations are rare. ${ }^{27}$

We propose the following reaction sequence (Scheme 4): (i) coordination of THF results in slippage of a bridging amido- 
Table 1 Selected distances $(\AA \AA)$ for the crystal structures of PYR-[MgNH(DIPP)BH $]_{2}$, PYR- $\left[\mathrm{Mg}_{2}(\mathrm{H}) \mathrm{NH}(\mathrm{DIPP}) \mathrm{BH}_{3}\right]_{2}(\mathrm{THF})$ and $\left[\mathrm{PYR}-(\mathrm{MgH})_{2}\right]_{2}$

\begin{tabular}{|c|c|}
\hline PYR-[MgN & $\left.\mathrm{H}_{3}\right]_{2}$ \\
\hline $\mathrm{Mg} 1-\mathrm{N} 1$ & $2.085(1)$ \\
\hline Mg1-N2 & $2.031(1)$ \\
\hline Mg1 $\cdots N 3$ & $2.780(1)$ \\
\hline Mg1-N6 & $2.121(1)$ \\
\hline Mg1 $\cdots B 2$ & $2.538(2)$ \\
\hline Mg1 $\cdots \mathrm{H} 6$ & $2.21(2)$ \\
\hline Mg1 $\cdots \mathrm{H} 7$ & $1.98(2)$ \\
\hline PYR- $\left[\mathrm{Mg}_{2}(\right.$ & $\left.\mathrm{BH}_{3}\right]_{2}($ \\
\hline $\mathrm{Mg} 1-\mathrm{H} 1$ & $1.95(2)$ \\
\hline Mg1-N1 & $2.081(2)$ \\
\hline Mg1-N2 & $2.093(2)$ \\
\hline Mg1-N6 & $2.093(2)$ \\
\hline Mg1B. & $2.649(3)$ \\
\hline [PYR-(MgF & \\
\hline $\mathrm{Mg} 1-\mathrm{H} 1$ & $1.83(2)$ \\
\hline Mg1-H3 & $1.84(2)$ \\
\hline $\mathrm{Mg} 2-\mathrm{H} 2$ & $1.79(2)$ \\
\hline $\mathrm{Mg} 2-\mathrm{H} 4$ & $1.82(2)$ \\
\hline $\mathrm{Mg} 3-\mathrm{H} 2$ & $1.81(2)$ \\
\hline Mg3-H3 & $1.79(2)$ \\
\hline Mg4-H1 & $1.86(2)$ \\
\hline $\mathrm{Mg} 4-\mathrm{H} 4$ & $1.81(2)$ \\
\hline
\end{tabular}

$\mathrm{Mg} 2 \cdots \mathrm{N} 3$

$\mathrm{Mg} 2-\mathrm{N} 4$

Mg2-N5

$\mathrm{Mg} 2-\mathrm{N} 7$

$\mathrm{Mg} 2 \cdots \mathrm{B} 1$

$\mathrm{Mg} 2 \cdots \mathrm{H} 3$

$\mathrm{Mg} 2 \cdots \mathrm{H} 4$

$\mathrm{Mg} 2-\mathrm{H} 1$

$\mathrm{Mg} 2-\mathrm{N} 3$

$\mathrm{Mg} 2-\mathrm{N} 4$

Mg2-N5

$\mathrm{Mg} 2-\mathrm{O} 1$

\section{Mg1-N1}

Mg1-N2

$\mathrm{Mg} 1 \cdots \mathrm{N} 3$

$\mathrm{Mg} 2-\mathrm{N} 4$

Mg2-N5

Mg3-N6

$\mathrm{Mg} 3-\mathrm{N} 7$

$\mathrm{Mg} 4 \cdots \mathrm{N} 8$

Mg4-N9

Mg4-N10
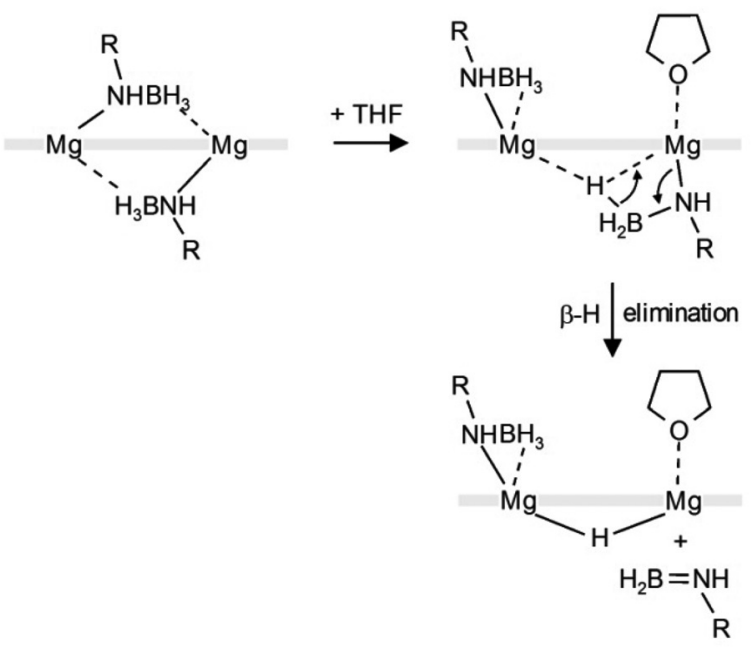

Scheme 4 Proposed mechanism for THF-induced hydride formation; front view (the thick grey line represents PYR).

borane ion to terminal coordination and $\mathrm{BH}_{3}$ group bridging two $\mathrm{Mg}^{2+}$ centers (in fact this intermediate has been observed earlier in the form of the $\mathbf{N N}-\left[\mathrm{MgNH}(i \mathrm{Pr}) \mathrm{BH}_{3}\right]_{2} \cdot \mathrm{THF}$ complex), ${ }^{23}$ (ii) this is followed by $\beta-\mathrm{H}$ elimination and formation of the product, (iii) the remaining $\operatorname{DIPPN}(\mathrm{H})=\mathrm{BH}_{2}$ decomposes to [(DIPP)NH $]_{2} \mathrm{BH}$ (detected by ${ }^{11} \mathrm{~B}$ NMR) and $\mathrm{BH}_{3}$ (detected in the form of $\mathrm{BH}_{4}{ }^{-}$by ${ }^{11} \mathrm{~B} \mathrm{NMR}$ ). The last step might go through an intermediate [DIPPN(H) $\mathrm{BH}_{2}(\mathrm{DIPP})-$ $\left.\mathrm{NHBH}_{3}\right]^{-}$anion. Similar intermediates have been isolated in early main group metal and transition metal chemistry. ${ }^{25,28-31}$
The very mild nature of this Lewis-base induced hydride formation, which is smooth at room temperature, posed the question whether a second $\mathrm{H}^{-}$elimination might open a new route for preparation of magnesium hydride complexes. Unfortunately, addition of larger amounts of THF (or using THF as the solvent) did not trigger further $\beta-\mathrm{H}$ elimination. Slowly increasing the temperature of the THF solution led to $\mathrm{H}_{2}$ formation, presumably by reaction of the $\mathrm{Mg}-\mathrm{H}$ function with $[(\mathrm{DIPP}) \mathrm{NH}]_{2} \mathrm{BH}$, and PYR-( $\left.\mathrm{MgH}\right)_{2}$ could not be isolated.

Therefore, we chose the slower but more effective phenylsilane route: ${ }^{8,9}$ reaction of a PYR-(Mgn $\left.n \mathrm{Bu}\right)_{2}$ solution in benzene with two equivalents of $\mathrm{PhSiH}_{3}$ gave the product at $60{ }^{\circ} \mathrm{C}$ after three days, which could be crystallized from hexane (54\%). The crystal structure of the dimer $\left[\text { PYR- }(\mathrm{MgH})_{2}\right]_{2}$ shows a near $C_{2}$-symmetric tetranuclear cluster without exact crystallographic symmetry (Fig. 1c, Table 1) but with some similarity to $\left[\mathbf{N N}-(\mathrm{MgH})_{2}\right]_{2} \cdot{ }^{14}$ Although composition and connectivity are similar, the arrangement of $\mathbf{M g}$ ions in $\left[\mathbf{P Y R}-(\mathrm{MgH})_{2}\right]_{2}$ is strongly distorted from the $\mathrm{Mg}_{4}$ tetrahedron found in $\left[\mathbf{N N}-(\mathrm{MgH})_{2}\right]_{2}$. Whereas in the latter $\mathbf{M g} \cdots \mathbf{M g}$ distances vary from 3.030(1) to 3.586(1) $\AA$, those in [PYR- $\left.(\mathrm{MgH})_{2}\right]_{2}$ are longer and show larger variation: 3.410(1)-4.293(1) ̊. This flattened $\mathrm{Mg}_{4}$ geometry is undoubtedly due to the large span width of the pyridylene bridged PYR ligand and results in an 8-membered ring of alternating $\mathrm{Mg}^{2+}$ and $\mathrm{H}^{-}$ions. However, the average $\mathrm{Mg}-\mathrm{H}$ distances ( $\mathrm{H}$ atoms have been located and were refined) are very similar in both structures: $\left[\mathbf{N N}-(\mathrm{MgH})_{2}\right]_{2}$ 1.808(9) and $\left[\text { PYR- }(\mathrm{MgH})_{2}\right]_{2}$ 1.82(2), but are naturally subject to a large error margin. The pyridylene $\mathrm{N}$ atoms are asymmetrically bridging the $\mathrm{Mg}^{2+}$ ions with shorter weakly-bound (2.614(2)/ 2.542(2) ̊) and longer essentially non-bonding (3.353(2)/ $3.407(2) \AA$ A) distances. Attempts to incorporate additional $\mathrm{MgH}_{2}$ into the cluster ( $c f$. (iv) in Scheme 2) by reaction of PYR$(\mathrm{Mg} n \mathrm{Bu})_{2} /(\mathrm{Mg} n \mathrm{Bu})_{2}$ mixtures with excess $\mathrm{PhSiH}_{3}$ failed.

The cluster $\left[\mathbf{P Y R}-(\mathrm{MgH})_{2}\right]_{2}$ contains three different hydride positions ( $\mathrm{H} 1, \mathrm{H} 3 / \mathrm{H} 4$ and $\mathrm{H} 2$ ). In case fast pyridyl-Mg1/ $\mathrm{Mg} 2$ and pyridyl-Mg4/Mg3 switching takes place, at least two different hydride positions are present $(\mathrm{H} 1 / \mathrm{H} 2$ and $\mathrm{H} 3 / \mathrm{H} 4)$. ${ }^{1} \mathrm{H}$ NMR spectra of $\left[\text { PYR- }(\mathrm{MgH})_{2}\right]_{2}$ in toluene- $d_{8}$, however, only show one singlet for the $\mathrm{H}^{-}$ligands. Cooling of the solution to $-75{ }^{\circ} \mathrm{C}$ did not result in decoalescence. This strongly contrasts with the dynamic behaviour observed for $\left[\mathrm{NN}-(\mathrm{MgH})_{2}\right]_{2}$ : below room temperature the singlet hydride signal decoalesces in two triplets. ${ }^{14}$ We presume that for $\left[\text { PYR- }(\mathrm{MgH})_{2}\right]_{2}$ the solid state structure is maintained in solution but fast dynamics of ligand coordination geometries result in equal hydride positions: a time-averaged structure with symmetrically bridging pyridylene units and flat PYR ligands would be $S_{4}$-symmetric. This is in agreement with the observation of two $i \operatorname{Pr}$ doublet signals and one $i$ Pr heptet signal. Although a monomeric PYR$(\mathrm{MgH})_{2}$ structure with bridging $\mathrm{H}^{-}$ligands (type i in Scheme 2) cannot be ruled out, $c f$. PYR-(MgnBu $)_{2},{ }^{23}$ in apolar solvents it seems the least stable option (especially if one considers the short $\mathrm{Mg}-\mathrm{H}$ bond distances of $1.8 \AA$ ).

The thermal decomposition of yellow crystals of [PYR$\left.(\mathrm{MgH})_{2}\right]_{2}$ was investigated by stepwise heating in a thermo- 
stated air-bath. At $130{ }^{\circ} \mathrm{C}$ the color changed via yellow-orange to dark red. Gas quantification by pumping the gas quantitatively into a calibrated burette of a Töpler pump system indicated the release of $1.1 \pm 0.1$ mol-equivalents of gas per $\left[\text { PYR- }(\mathrm{MgH})_{2}\right]_{2}$. Extended heating did not result in more gas elimination. The gas was proven to be $\mathrm{H}_{2}$ : (i) it does not condense in liquid $\mathrm{N}_{2}$ but is fully converted to condensable water after leading it over $\mathrm{CuO}$ of $300{ }^{\circ} \mathrm{C}$; (ii) after leading the gas in deuterated THF, a clear ${ }^{1} \mathrm{H}$ NMR resonance could be observed at $4.55 \mathrm{ppm}$ which is the chemical shift for $\mathrm{H}_{2}$ in this solvent. ${ }^{18}$

Thermal $\mathrm{H}_{2}$ desorption from the $\left[\mathbf{P Y R}-(\mathrm{MgH})_{2}\right]_{2}$ cluster differs from the earlier reported results for $\left[\mathbf{N N}-(\mathrm{MgH})_{2}\right]_{2}$ : hydrogen is released at the significantly lower temperature of $130{ }^{\circ} \mathrm{C}\left(v s .175{ }^{\circ} \mathrm{C}\right)$ and only $50 \%$ of the theoretical hydrogen content could be detected (vs. full conversion). This is likely due to the fact that pyridine is susceptible towards nucleophilic addition of $\mathrm{H}^{-}$in ortho- or para-positions to form a dearomatized amide. Proposed nucleophilic attack at the paraposition (Scheme 3) explains reduced $\mathrm{H}_{2}$ release. In contrast to $\left[\mathrm{NN}-(\mathrm{MgH})_{2}\right]_{2}$, which when dissolved in toluene is stable even after prolonged heating at $150{ }^{\circ} \mathrm{C}$, a toluene solution of [PYR- $\left.(\mathrm{MgH})_{2}\right]_{2}$ decomposes by a colour change from yellow to dark-red after one hour at this temperature. ${ }^{1} \mathrm{H}$ NMR analysis indicates dearomatization of the pyridyl ring, but due to the presence of several different species, no well-defined products could be isolated. We propose initial formation of a dihydropyridide bridged $\beta$-diketiminate- $\mathrm{Mg}(\mathrm{I})$ complex (Scheme 3) which decomposes into various undefined species.

\section{Conclusions}

The magnesium hydride chemistry with the 2,6-pridylene bridged bis- $\beta$-diketiminate ligand, PYR, has been investigated. Although one of the amidoborane anions in PYR-[MgNH(DIPP) $\left.\mathrm{BH}_{3}\right]_{2}$ could be converted into $\mathrm{H}^{-}$by a THF-induced $\beta-\mathrm{H}$ elimination, such a transformation could not be achieved for the second amidoborane anion. Reaction of PYR- $(\mathrm{Mg} n \mathrm{Bu})_{2}$ with $\mathrm{PhSiH}_{3}$ gave the desired magnesium hydride complex in the form of the dimer $\left[\mathbf{P Y R}-(\mathrm{MgH})_{2}\right]_{2}$. Attempts to incorporate additional $\mathrm{MgH}_{2}$ into the cluster failed. The structure of [PYR$\left.(\mathrm{MgH})_{2}\right]_{2}$ is different from that reported previously for $[\mathbf{N N}-$ $\left.(\mathrm{MgH})_{2}\right]_{2}$, a complex with directly coupled $\beta$-diketiminate units and four $\mathrm{Mg}^{2+}$ ions at the corners of a tetrahedron. Instead, a flattened $\mathrm{Mg}_{4}$ geometry is found in which alternating $\mathrm{Mg}^{2+}$ and $\mathrm{H}^{-}$ions form an 8-membered ring. [PYR- $\left.(\mathrm{MgH})_{2}\right]_{2}$ decomposes at $130{ }^{\circ} \mathrm{C}$ releasing one equivalent of $\mathrm{H}_{2}$. In contrast, $\left[\mathbf{N N}-(\mathrm{MgH})_{2}\right]_{2}$ decomposes at $175^{\circ} \mathrm{C}$ and releases two equivalents of $\mathrm{H}_{2}$. It is proposed that nucleophilic attack at the paraposition explains reduced $\mathrm{H}_{2}$ formation (Scheme 3). Although the fate of the magnesium is unclear, it is likely that low-valent magnesium species were formed initially. We continue our investigations with the challenging isolation of larger welldefined $\mathrm{Mg}(\mathrm{I})$ clusters.

\section{Experimental}

\section{General}

All experiments were carried out using standard Schlenk-techniques and freshly dried solvents. The following compounds were prepared according to the literature: PYR $-\mathrm{H}_{2},{ }^{22}$ PYR$[\mathrm{Mg}(n \mathrm{Bu})]_{2},{ }^{23}$ (DIPP) $\mathrm{NH}_{2} \mathrm{BH}_{3} .{ }^{32}$ NMR spectra were measured using a Bruker DPX300 and DRX500 spectrometer. Crystals were measured using a Siemens Smart diffractometer with APEXII area detector system.

\section{Syntheses}

PYR-[MgNH(DIPP)BH $\left.]_{3}\right]_{2} .408 \mathrm{mg}(0.542 \mathrm{mmol})$ PYR-[Mg$(n \mathrm{Bu})]_{2}$ was dissolved in $10 \mathrm{~mL}$ of toluene and the solution was cooled to $-78{ }^{\circ} \mathrm{C}$ in an $i \mathrm{PrOH} / \mathrm{CO}_{2}$ cooling bath. At this temperature, a solution of $207 \mathrm{mg}(1.08 \mathrm{mmol})(\mathrm{DIPP}) \mathrm{NH}_{2} \mathrm{BH}_{3}$ in $2 \mathrm{~mL}$ of toluene was added slowly. The reaction mixture was stirred and the cooling bath slowly warmed to room temperature overnight. The solution was concentrated to half its volume and slowly cooled to $-27^{\circ} \mathrm{C}$. The product PYR-[MgNH(DIPP) $\left.\mathrm{BH}_{3}\right]_{2}$ was crystallized in the form of large yellow blocks. Yield: $310 \mathrm{mg}, 0.304 \mathrm{mmol}, 56 \%$. Elemental analysis (\%) calcd for $\mathrm{C}_{63} \mathrm{H}_{93} \mathrm{~B}_{2} \mathrm{Mg}_{2} \mathrm{~N}_{7}\left(M_{\mathrm{r}}=1018.69\right)$ : $\mathrm{C}$ 74.28, H 9.20; found C 74.48, H 9.00.

${ }^{1} \mathrm{H}\left\{{ }^{11} \mathrm{~B}\right\}$ NMR (500 MHz, toluene- $\left.d_{8},-40{ }^{\circ} \mathrm{C}\right): \delta=0.19(\mathrm{~d}$, $\left.{ }^{3} J(\mathrm{H}, \mathrm{H})=6.3 \mathrm{~Hz}, 6 \mathrm{H}, i \mathrm{Pr}\right), 0.62\left(\mathrm{~d},{ }^{3} J(\mathrm{H}, \mathrm{H})=6.2 \mathrm{~Hz}, 6 \mathrm{H}, i \mathrm{Pr}\right)$, $0.86\left(\mathrm{~d},{ }^{3} J(\mathrm{H}, \mathrm{H})=6.5 \mathrm{~Hz}, 6 \mathrm{H}, i \operatorname{Pr}\right), 0.95\left(\mathrm{~d},{ }^{3} J(\mathrm{H}, \mathrm{H})=6.3 \mathrm{~Hz}\right.$, $6 \mathrm{H}, i \mathrm{Pr}), 1.19\left(\mathrm{~d},{ }^{3} J(\mathrm{H}, \mathrm{H})=6.0 \mathrm{~Hz}, 6 \mathrm{H}, i \mathrm{Pr}\right), 1.25\left(\mathrm{~d},{ }^{3} J(\mathrm{H}, \mathrm{H})=\right.$ $6.5 \mathrm{~Hz}, 6 \mathrm{H}, i \mathrm{Pr}), 1.42\left(\mathrm{~d},{ }^{3} J(\mathrm{H}, \mathrm{H})=6.2 \mathrm{~Hz}, 6 \mathrm{H}, i \mathrm{Pr}\right), 1.44(\mathrm{~s}, 6 \mathrm{H}$, Me backbone), $1.49\left(\mathrm{~d},{ }^{3} J(\mathrm{H}, \mathrm{H})=6.0 \mathrm{~Hz}, 6 \mathrm{H}, i \mathrm{Pr}\right), 1.98(\mathrm{~s}, 6 \mathrm{H}$, Me backbone), 2.28 (br, $\left.6 \mathrm{H}, \mathrm{BH}_{3}\right), 2.64\left(\mathrm{sept},{ }^{3} J(\mathrm{H}, \mathrm{H})=6.2 \mathrm{~Hz}\right.$, $2 \mathrm{H}, i \mathrm{Pr}$ ), $2.81\left(\mathrm{sept},{ }^{3} J(\mathrm{H}, \mathrm{H})=6.3 \mathrm{~Hz}, 2 \mathrm{H}, i \mathrm{Pr}\right), 3.13(\mathrm{br}, 2 \mathrm{H}$, $\mathrm{NH}), 3.17$ (sept, $\left.{ }^{3} J(\mathrm{H}, \mathrm{H})=6.5 \mathrm{~Hz}, 2 \mathrm{H}, i \mathrm{Pr}\right), 3.59\left(\mathrm{sept},{ }^{3} J(\mathrm{H}, \mathrm{H})=\right.$ $6.0 \mathrm{~Hz}, 2 \mathrm{H}, i \mathrm{Pr}), 4.79\left(\mathrm{~s}, 2 \mathrm{H}, \mathrm{H}\right.$ backbone), $6.34\left(\mathrm{~d},{ }^{3} \mathrm{~J}(\mathrm{H}, \mathrm{H})=\right.$ $8.0 \mathrm{~Hz}, 2 \mathrm{H}, \operatorname{aryl}), 6.78\left(\mathrm{~d},{ }^{3} J(\mathrm{H}, \mathrm{H})=6.4 \mathrm{~Hz}, 2 \mathrm{H}, \operatorname{aryl}\right), 6.94(\mathrm{t}$, ${ }^{3} J(\mathrm{H}, \mathrm{H})=8.0 \mathrm{~Hz}, 1 \mathrm{H}$, aryl $), 6.97-7.07(\mathrm{~m}, 8 \mathrm{H}, \operatorname{aryl}), 7.12(\mathrm{~m}$, $2 \mathrm{H}$, aryl). ${ }^{11} \mathrm{~B}$ NMR $\left(160 \mathrm{MHz}\right.$, toluene- $\left.d_{8}, 20{ }^{\circ} \mathrm{C}\right): \delta=-18.0(\mathrm{br})$. ${ }^{13} \mathrm{C}$ NMR (data taken from 2D-spectra, $75 \mathrm{MHz}$, toluene- $d_{8}$, $\left.-40{ }^{\circ} \mathrm{C}\right): \delta=23.2(i \mathrm{Pr}), 24.6(i \mathrm{Pr}), 24.6$ (Me backbone), 24.6 ( $i \mathrm{Pr}$ ), 24.8 ( $i \mathrm{Pr}$ ), $25.0(i \mathrm{Pr}), 25.3(i \mathrm{Pr}), 25.3$ (Me Backbone), 25.9 (iPr), 27.3 (iPr), 27.4 (iPr), 28.3 (iPr), $28.4(i \mathrm{Pr}), 29.1$ (iPr), 100.0 (backbone), 110.7 (aryl), 122.9 (aryl), 123.7 (aryl), 124.1 (aryl), 124.2 (aryl), 125.2 (aryl), 126.4 (aryl), 138.4 (aryl), 139.7 (aryl), 140.9 (aryl), 142.3 (aryl), 142.3 (aryl), 145.5 (aryl), 145.6 (aryl), 161.1 (aryl), 162.5 (backbone), 173.1 (backbone).

PYR-[Mg ${ }_{2}$ (H)NH(DIPP)BH $]_{2}$ (THF). $200 \mathrm{mg}(0.196 \mathrm{mmol})$ PYR-[MgNH(DIPP) $\left.\mathrm{BH}_{3}\right]_{2}$ was dissolved in $3.5 \mathrm{~mL}$ of THF. After three hours, yellow crystalline blocks of PYR-[ $\mathrm{Mg}_{2}(\mathrm{H}) \mathrm{NH}(\mathrm{DIPP})-$ $\left.\mathrm{BH}_{3}\right]_{2}(\mathrm{THF})_{3}$ were separated. The product was isolated by centrifugation, the mother liquor was removed and subsequently washed with $2.0 \mathrm{~mL}$ of hexane and shortly dried in high vacuum. Yield of PYR- $\left[\mathrm{Mg}_{2}(\mathrm{H}) \mathrm{NH}(\mathrm{DIPP}) \mathrm{BH}_{3}\right]_{2}(\mathrm{THF})_{3}: 85 \mathrm{mg}$, $0.081 \mathrm{mmol}, 41 \%$. Note that, instead of one THF, three equivalents of THF are included. This is due to cocrystallized nonbonding THF ligands (see below). The mother liquor of the reaction mixture gave another crop of the microcrystalline 
product: the solvents were removed under high vacuum and the remaining solid was washed with $2.0 \mathrm{~mL}$ of hexane and dried under high vacuum. The combined yields of PYR$\left[\mathrm{Mg}_{2}(\mathrm{H}) \mathrm{NH}(\mathrm{DIPP}) \mathrm{BH}_{3}\right]_{2}(\mathrm{THF})_{3}$ are $117 \mathrm{mg}, 0.112 \mathrm{mmol}, 57 \%$. Crystals for crystal structure determination were obtained by recrystallization from a $5 / 1$ benzene-THF mixture. The constitution is PYR- $\left[\mathrm{Mg}_{2}(\mathrm{H}) \mathrm{NH} \text { (DIPP) } \mathrm{BH}_{3}\right]_{2}(\mathrm{THF})$; two disordered benzene molecules instead of THF molecules cocrystallized. Elemental analysis for the first batch of well-defined crystals (\%) calcd for $\mathrm{C}_{63} \mathrm{H}_{97} \mathrm{BMg}_{2} \mathrm{~N}_{6} \mathrm{O}_{3}\left(M_{\mathrm{r}}=1045.90\right)$ : $\mathrm{C} 72.35, \mathrm{H}$ 9.35; found $\mathrm{C} 72.34, \mathrm{H}$ 9.16. ${ }^{1} \mathrm{H}\left\{{ }^{11} \mathrm{~B}\right\} \mathrm{NMR}\left(500 \mathrm{MHz}, \mathrm{THF}-d_{8}, 20{ }^{\circ} \mathrm{C}\right)$ : $\delta=1.06\left(\mathrm{~d},{ }^{3} J(\mathrm{H}, \mathrm{H})=6.3 \mathrm{~Hz}, 12 \mathrm{H}, i \mathrm{Pr} \mathrm{NH}\right), 1.08(\mathrm{br}, 12 \mathrm{H}, i \mathrm{Pr})$, $1.11\left(\mathrm{~d},{ }^{3} J(\mathrm{H}, \mathrm{H})=6.4 \mathrm{~Hz}, 12 \mathrm{H}, i \mathrm{Pr}\right), 1.58\left(\mathrm{br}, 3 \mathrm{H}, \mathrm{BH}_{3}\right) 1.63(\mathrm{~s}$ (br), 6H, Me backbone), 1.78 (m, 12H, THF), 2.13 (s (br), 6H, Me backbone), 2.61 (q (br), $\left.{ }^{3} J(\mathrm{H}, \mathrm{H})=3.4 \mathrm{~Hz}, 1 \mathrm{H}, \mathrm{NH}\right), 2.95$ (sept, $\left.{ }^{3} J(\mathrm{H}, \mathrm{H})=6.4 \mathrm{~Hz}, 2 \mathrm{H}, i \operatorname{Pr} \mathrm{NH}\right), 3.09$ (br, 4H, $\left.i \mathrm{Pr}\right), 3.21$ (s, 1H, MgH), 3.62 (m, 12H, THF), 4.78 (s (br), 2H, H backbone), $6.20(\mathrm{br}, 1 \mathrm{H}$, aryl $), 6.59(\mathrm{br}, 2 \mathrm{H}$, aryl $\mathrm{NH}), 6.69\left(\mathrm{~d},{ }^{3} J(\mathrm{H}, \mathrm{H})=\right.$ $6.7 \mathrm{~Hz}, 2 \mathrm{H}$, aryl $\mathrm{NH}), 7.00-7.12\left(\mathrm{~m}, 7 \mathrm{H}\right.$, aryl). ${ }^{11} \mathrm{~B} \mathrm{NMR}$ $\left(160 \mathrm{MHz}, \mathrm{THF}-d_{8}, 20{ }^{\circ} \mathrm{C}\right): \delta=-18.1$ (br). ${ }^{13} \mathrm{C}$ NMR (data taken from 2D spectra, $75 \mathrm{MHz}$, THF- $d_{8}, 20^{\circ} \mathrm{C}$ ): 24.3 (Me backbone), 25.1 ( $i \mathrm{Pr}), 25.2(i \mathrm{Pr}), 25.2$ ( $i \mathrm{Pr}), 25.5$ (Me backbone), 26.2 (THF), 29.2 ( $i$ Pr), 29.7 (iPr), 68.2 (THF), 99.2 (backbone), 120.0 (aryl NH), 123.0 (aryl), 124.2 (aryl), 125.8 (aryl), 139.2 (aryl NH), 142.2 (aryl), 146.2 (aryl), 148.6 (aryl), 160.5 (aryl), 161.9 (backbone), 172.1 (backbone).

[PYR-(MgH $\left.)_{2}\right]_{2}$. A solution of phenylsilane $(90 \mathrm{mg}$, $0.832 \mathrm{mmol})$ and PYR- $[\mathrm{Mg}(n \mathrm{Bu})]_{2}(300 \mathrm{mg}, 0.399 \mathrm{mmol})$ in $6 \mathrm{~mL}$ of benzene was heated to $60{ }^{\circ} \mathrm{C}$ for three days. The solvent was removed under high vacuum and the residue was dissolved in $2 \mathrm{~mL}$ of hexane. After two days at room temperature yellow crystals formed. Yield: $138 \mathrm{mg}, 0.108 \mathrm{mmol}, 54 \%$. Elemental analysis (\%) calcd for $\mathrm{C}_{78} \mathrm{H}_{106} \mathrm{Mg}_{4} \mathrm{~N}_{10} \quad\left(M_{\mathrm{r}}=\right.$ 1280.97): C 73.14, $\mathrm{H}$ 8.34; found $\mathrm{C} 73.36, \mathrm{H}$ 8.38. ${ }^{1} \mathrm{H}$ NMR (300 MHz, benzene- $\left.d_{6}, 20{ }^{\circ} \mathrm{C}\right): \delta=0.96\left(\mathrm{~d},{ }^{3} J(\mathrm{H}, \mathrm{H})=6.8 \mathrm{~Hz}\right.$, 12H, $i$ Pr), $1.16\left(\mathrm{~d},{ }^{3} J(\mathrm{H}, \mathrm{H})=7.0 \mathrm{~Hz}, 12 \mathrm{H}, i \mathrm{Pr}\right), 1.57$ (s, 6H, Me backbone), 1.82 (s, 6H, Me backbone), 2.88 (s, 2H, MgH), 3.14 (sept, $\left.{ }^{3} J(\mathrm{H}, \mathrm{H})=6.8 \mathrm{~Hz}, 4 \mathrm{H}, i \mathrm{Pr}\right), 4.79$ (s, 2H, H backbone), 6.12 $\left(\mathrm{d},{ }^{3} J(\mathrm{H}, \mathrm{H})=7.9 \mathrm{~Hz}, 2 \mathrm{H}\right.$, aryl), 6.99-7.03 (m, 6H, aryl) 7.03 $\left(\mathrm{t},{ }^{3} J(\mathrm{H}, \mathrm{H})=7.9 \mathrm{~Hz}, 1 \mathrm{H}\right.$, aryl). ${ }^{13} \mathrm{C}$ NMR (75 MHz, benzene- $d_{6}$, $20{ }^{\circ} \mathrm{C}$ ): 24.6 (Me backbone), 24.6 (iPr), 24.7 (Me backbone), 25.0 ( $i \mathrm{Pr}$ ), 28.6 ( $i \mathrm{Pr}$ ), 99.7 (backbone), 111.3 (aryl), 124.1 (aryl), 125.7 (aryl), 138.1 (aryl), 142.4 (aryl), 146.1 (aryl), 162.5 (aryl), 164.0 (aryl), 170.8 (backbone).

\section{Crystal structure determinations}

The structures were solved by direct methods (SHELXS-97) ${ }^{33}$ and refined with SHELXL-97. ${ }^{34}$ All geometry calculations and graphics were performed with PLATON. ${ }^{35}$

PYR-[MgNH(DIPP)BH $\left.]_{3}\right]_{2}$. Measurement at $-170{ }^{\circ} \mathrm{C}\left(\mathrm{Mo}_{\mathrm{K \alpha}}\right)$, formula $\left[\left(\mathrm{C}_{63} \mathrm{H}_{93} \mathrm{~B}_{2} \mathrm{Mg}_{2} \mathrm{~N}_{7}\right), 3.5\left(\mathrm{C}_{6} \mathrm{H}_{6}\right)\right], M_{\mathrm{w}}=1292.06$, triclinic, $a=14.5633(10) \AA, b=15.0972(10) \AA, c=20.1383(12) \AA, \alpha=$ $88.321(2)^{\circ}, \beta=71.161(2)^{\circ}, \gamma=68.872(2)^{\circ}, V=3889.8(4) \AA^{3}$, space group $P \overline{1}, Z=2, \rho_{\text {calc }}=1.103 \mathrm{~g} \mathrm{~cm}^{-3}, \mu(\mathrm{MoK} \alpha)=$ $0.078 \mathrm{~mm}^{-1}$, 53697 measured reflections, 15620 independent reflections $\left(R_{\mathrm{int}}=0.029\right), 12390$ reflections observed with
$I>2 \sigma(I), \theta_{\max }=26.4^{\circ}, R=0.0401, \mathrm{w} R_{2}=0.1043, \mathrm{GOF}=1.03$, 1128 parameter, $\mathrm{min} / \mathrm{max}$ residual electron density

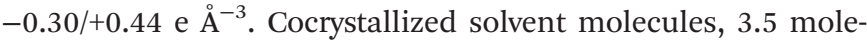
cules of benzene, were relatively well-ordered and refined anisotropically. All hydrogen atoms, except those of cocrystallized benzene molecules, were found in the difference-Fourier map and were refined isotropically. Hydrogen atoms on the benzene molecules were placed on idealized calculated positions.

PYR- $\left[\mathbf{M g}_{2} \text { (H)NH(DIPP)BH }\right]_{2}$ (THF). Measurement at $-156{ }^{\circ} \mathrm{C}$ $\left(\mathrm{Mo}_{\mathrm{K} \alpha}\right)$, formula $\left[\mathrm{C}_{55} \mathrm{H}_{81} \mathrm{BMg}_{2} \mathrm{~N}_{6} \mathrm{O}\right], M_{\mathrm{w}}=901.69$, orthorhombic, $a=13.4280(7) \AA, b=20.4076(10) \AA, c=21.3571(10) \AA, V=$ $5852.6(5) \AA^{3}$, space group $P 2_{1} 2_{1} 2_{1}, Z=4, \rho_{\text {calc }}=1.023 \mathrm{~g} \mathrm{~cm}^{-3}$, $\mu(\mathrm{MoK} \alpha)=0.080 \mathrm{~mm}^{-1}, 20850$ measured reflections, 10889 independent reflections $\left(R_{\text {int }}=0.038\right), 9207$ reflections observed with $I>2 \sigma(I), \theta_{\max }=26.5^{\circ}, R=0.0480, \mathrm{w} R_{2}=0.1260$, $\mathrm{GOF}=1.06,621$ parameter, $\mathrm{min} / \mathrm{max}$ residual electron density $-0.24 /+0.61$ e $\AA^{-3}$. Two cocrystallized molecules of heavily disordered benzene were treated by the SQUEEZE procedure incorporated in PLATON $\left(214 \AA^{3}, 98\right.$ e). ${ }^{15}$ The hydride and hydrogens on $\mathrm{N}$ and $\mathrm{B}$ were found in the difference-Fourier map and refined isotropically. All other hydrogen atoms have been placed on calculated positions and were refined in a riding mode. The correct handedness of the chiral unit cell has been checked by refinement of the Flack parameter to 0.01 with esd 0.18 .

[PYR-(MgH $\left.)_{2}\right]_{2}$. Measurement at $-170{ }^{\circ} \mathrm{C}\left(\mathrm{Mo}_{\mathrm{K} \alpha}\right)$, formula $\left[\left(\mathrm{C}_{78} \mathrm{H}_{106} \mathrm{Mg}_{4} \mathrm{~N}_{10}\right)\right], M_{\mathrm{W}}=1280.97$, monoclinic, $a=24.0463(16)$ $\AA, b=15.4013(10) \AA, c=22.4206(15) \AA, \beta=103.909(4)^{\circ}, V=$ 8059.9(9) $\AA^{3}$, space group $P 2_{1} / c, Z=4, \rho_{\text {calc }}=1.056 \mathrm{~g} \mathrm{~cm}^{-3}$, $\mu(\operatorname{MoK} \alpha)=0.090 \mathrm{~mm}^{-1}, 83576$ measured reflections, 15303 independent reflections $\left(R_{\mathrm{int}}=0.077\right), 15303$ reflections observed with $I>2 \sigma(I), \theta_{\max }=25.8^{\circ}, R=0.0487, \mathrm{w} R_{2}=0.1165$, $\mathrm{GOF}=0.94,1228$ parameter, $\mathrm{min} / \mathrm{max}$ residual electron density $-0.24 /+0.43$ e $\AA^{-3}$. Heavily disordered cocrystallized solvent was treated by the SQUEEZE procedure incorporated in PLATON (290 $\AA^{3}, 52$ e). ${ }^{15}$ One of the $i$ Pr groups shows rotational disorder over two positions that were refined isotropically. Hydrogen atoms were found in the difference-Fourier map and were refined isotropically, except for those on the disordered $i$ Pr group. The latter were placed on idealized positions and refined in a riding mode.

Crystallographic data (excluding structure factors) have been deposited with the Cambridge Crystallographic Data Centre as supplementary publication no. CCDC 992444-992446 for PYR-[MgNH(DIPP)BH $\left.\mathrm{BH}_{3}\right](\mathrm{MgH}) \cdot \mathrm{THF}$, PYR$\left[\mathrm{MgNH}(\mathrm{DIPP}) \mathrm{BH}_{3}\right]_{2}$, and $\left[\mathbf{P Y R}-(\mathrm{MgH})_{2}\right]_{2}$, respectively.

\section{Acknowledgements}

The DFG is gratefully acknowledged for financial support. Prof. R. Boese and D. Bläser are thanked for measuring X-ray data and $\mathrm{H}$. Bandmann for measuring the $500 \mathrm{MHz}$ NMR spectra. 


\section{Notes and references}

1 G. S. McGrady and G. Guilera, Chem. Soc. Rev., 2003, 32, 383.

2 S. Aldridge and A. J. Downs, Chem. Rev., 2001, 101, 3305.

3 P. Rittmeyer and U. Wietelmann, Hydrides, in Ullmann's Encyclopedia of Industrial Chemistry, Wiley-VCH, 2012, p. 103.

4 S. Harder, Chem. Commun., 2012, 48, 11165.

5 D. Hoffmann, T. Kottke, R. J. Lagow and R. D. Thomas, Angew. Chem., Int. Ed., 1998, 37, 1537.

6 D. R. Armstrong, W. Clegg, R. P. Davies, S. T. Liddle, D. J. Linton, P. R. Raithby, R. Snaith and A. E. H. Wheatley, Angew. Chem., Int. Ed., 1999, 38, 3367.

7 D. J. Gallagher, K. W. Henderson, A. R. Kennedy, C. T. O'Hara, R. E. Mulvey and R. B. Rowlings, Chem. Commun., 2002, 376.

8 S. Harder and J. Brettar, Angew. Chem., Int. Ed., 2006, 45, 3474.

9 S. P. Green, C. Jones and A. Stasch, Angew. Chem., Int. Ed., 2008, 47, 9079.

10 M. Arrowsmith, M. S. Hill, D. J. MacDougall and M. F. Mahon, Angew. Chem., Int. Ed., 2009, 48, 4013.

11 S. Harder, J. Spielmann, J. Intemann and H. Bandmann, Angew. Chem., Int. Ed., 2011, 50, 4156.

12 (a) A. Stasch, Angew. Chem., Int. Ed., 2012, 51, 1930; (b) C. Appelt, J. C. Slootweg, K. Lammertsma and W. Uhl, Angew. Chem., Int. Ed., 2012, 51, 5911.

13 P. Jochmann, J. P. Davin, T. P. Spaniol, L. Maron and J. Okuda, Angew. Chem., Int. Ed., 2012, 51, 2098.

14 J. Intemann, J. Spielmann, P. Sirsch and S. Harder, Chem. Eur. J., 2013, 19, 8478.

15 A. Stasch, Angew. Chem., Int. Ed., 2014, 53, 1338.

16 F. Buch, J. Brettar and S. Harder, Angew. Chem., Int. Ed., 2006, 45, 2741.

17 J. Spielmann, F. Buch and S. Harder, Angew. Chem., Int. Ed., 2008, 47, 9434.

18 S. Harder, Chem. Rev., 2010, 110, 3852.

19 A. G. M. Barrett, M. R. Crimmin, M. S. Hill and P. A. Procopiou, Proc. R. Soc. London, Ser. A., 2010, 466, 927.
20 S. J. Bonyhady, D. Collis, G. Frenking, N. Holzmann, C. Jones and A. Stasch, Nat. Chem., 2010, 2, 865.

21 R. W. P. Wagemans, J. H. van Lenthe, P. E. de Jongh, A. J. van Dillen and K. P. de Jong, J. Am. Chem. Soc., 2005, 127, 16675.

22 D. F.-J. Piesik, S. Range and S. Harder, Organometallics, 2008, 27, 6178.

23 J. Spielmann, D. F.-J. Piesik and S. Harder, Chem. - Eur. J., 2010, 16, 8307.

24 H. Gehring, R. Metzinger, C. Hertwig, J. Intemann, S. Harder and C. Limberg, Chem. - Eur. J., 2013, 19, 1629.

25 J. Spielmann, M. Bolte and S. Harder, Chem. Commun., 2009, 6934

26 (a) P. S. Braterman and R. J. Cross, Chem. Soc. Rev., 1973, 2, 271; (b) G. F. Schmidt and M. Brookhart, J. Am. Chem. Soc., 1985, 107, 1443; (c) B. J. Burger, M. E. Thompson, W. D. Cotter and J. E. Bercaw, J. Am. Chem. Soc., 1990, 112, 1566.

27 (a) K. Yan, J. J. D. Heredia, A. Ellern, M. S. Gordon and A. D. Sadow, J. Am. Chem. Soc., 2013, 135, 15225; (b) D. Mukherjee, A. Ellern and A. D. Sadow, J. Am. Chem. Soc., 2010, 132, 7582.

28 D. J. Liprot, M. S. Hill, M. F. Mahon and D. J. MacDougall, Chem. - Eur. J., 2010, 16, 8508.

29 T. B. Marder, Angew. Chem., Int. Ed., 2007, 46, 8116.

30 C. W. Hamilton, R. T. Baker, A. Staubitz and I. Manners, Chem. Soc. Rev., 2009, 38, 27.

31 D. Y. Kim, N. J. Singh, H. M. Lee and K. S. Kim, Chem. Eur. J., 2009, 15, 5598.

32 J. Spielmann and S. Harder, J. Am. Chem. Soc., 2009, 131, 5064.

33 G. M. Sheldrick, SHELXS-97, Program for Crystal Structure Solution, Universität Göttingen, Göttingen (Germany), 1997.

34 G. M. Sheldrick, SHELXL-97, Program for Crystal Structure Refinement, Universität Göttingen, Göttingen (Germany), 1997.

35 A. L. Spek, Platon, A Multipurpose Crystallographic Tool, Utrecht (The Netherlands), 2000. 